\title{
Forecasting on Indonesian Coal Production and Future Extraction Cost: A Tool for Formulating Policy on Coal Marketing
}

\author{
Fadhila Achmadi Rosyid ${ }^{1,2}$, Tsuyoshi Adachi ${ }^{3}$ \\ ${ }^{1}$ Graduate School of Engineering and Resources Science, Akita University, Akita, Japan \\ ${ }^{2}$ Department of Mining Engineering, Institut Teknologi Bandung, Bandung, Indonesia \\ ${ }^{3}$ Faculty of International Resources Science, Akita University, Akita, Japan \\ Email: fadhila@mining.itb.ac.id, adachi.t@gipc.akita-u.ac.jp
}

How to cite this paper: Rosyid, F.A. and Adachi, T. (2016) Forecasting on Indonesian Coal Production and Future Extraction Cost: A Tool for Formulating Policy on Coal Marketing. Natural Resources, 7, 677-696. http://dx.doi.org/10.4236/nr.2016.712054

Received: August 15, 2016

Accepted: December 3, 2016

Published: December 6, 2016

Copyright $\odot 2016$ by authors and Scientific Research Publishing Inc. This work is licensed under the Creative Commons Attribution International License (CC BY 4.0).

http://creativecommons.org/licenses/by/4.0/ (c) (i) Open Access

\section{Abstract}

Since 2011 Indonesia has become the world's largest exporter of steam coal. Two supporting factors of Indonesia to be the largest exporter are its enormous production and low operating cost. This paper foresees the production and extraction cost of Indonesian coal in the coming period to evaluate marketing policies and estimate the cost of Indonesian coal supply in domestic market as well as in export market. The production forecasting is carried out by Gompertz curve. Peak production of Indonesian coal is expected to take place in 2026. Moreover, the extraction cost in coal basins which produce high calorific value of coal, in accordance to the operating cost forecasting, is higher than the one with low calorific value of coal due to its higher stripping ratio. Three main basins of Central Sumatra, Tarakan, and Barito basins play major rule in supplying coal for domestic use in short term. And other coal basins such as South Sumatra, Kutai, Bengkulu, and Ombilin basins provide long term supply in the domestic and export markets.

\section{Keywords}

Indonesian Coal, Production Forecast, Cost Estimates

\section{Introduction}

Indonesia is the country's largest steam coal exporter in the world. Its steam coal supply continues to increase approximately $17 \%$ per year and accommodates approximately $20 \%$ of the total volume of coal trading in the international market every year [1]. The main factor to support its existence as the largest steam coal supplier is the growth of 
national coal production. Since the last 10 years Indonesia's coal production increases by $17 \%$ per year, while the domestic consumption only increases by about $10 \%$ per year. In addition to the rapid growth in production, the supply cost of Indonesian coal is another factor to support the Indonesian coal export in the international market. Data in 2010 showed cash costs include Indonesian coal royalty of USD 36 per ton. Among all the coal producing countries, it is the third lowest after South Africa and Columbia [2].

The future of Indonesian coal production is captivating to discuss considering its position as the largest steam coal supplier. Some researchers have carried out prominent studies on the future of Indonesian coal production. They are the Indonesian Coal Mining Association (ICMA) (2010), Mohr and Evans (2009), Paztek and Croft (2010), and Hook et al. (2010) [3] [4] [5] [6]. ICMA predicted the Indonesian coal production in 2015 is about 560 million tons by examining the existing infrastructure capability [3]. Based on BP Statistical Review 2013 data, the Indonesian coal reserves are about 31 billion tonnes, only $3.1 \%$ of total world coal reserves [7]. With current production level of approximately 400 million tons per year, the available reserves will only last for 67 years [8].

With respect to the production and supply of Indonesian coal in the export market, this research will focus on the production and cost forecasting of coal extraction. Extraction cost in which its value is equivalent to the operating costs is drawn an attention as, for non-renewable resource, it is a function of cumulative production. This condition may affect the comparative advantages of Indonesian coal in the export market. The coal production forecasting will be carried out using the Gompertz curve method to the respective coal basins. Operating cost will be predicted based on trend analysis of the profitability value of coal exploitation in every coal basin. Coal basin approach is chosen as it accommodates coal quality aspect which influences the depletion rate of the coal and the profitability value of the coal exploitation.

\section{Coal Mining in Indonesia}

Coal in Indonesia is mainly mined in 7 economic coal basins located in Sumatra and Kalimantan (Figure 1). Potential coal basins in Kalimantan are Tarakan, Kutai, and Barito. And potential coal basins in Sumatra are Ombilin, Bengkulu, Central Sumatra and South Sumatra. Currently Indonesia's total coal reserves are around 31 Billion tonnes; approximately $58 \%$ of total reserves are in Kalimantan and the rest are in Sumatra. Kutai Basin has the largest reserves, around 12.8 Billion tonnes, followed by South Sumatra and Barito basins, around 12 billion tonnes and 4.7 billion tonnes, respectively [7].

Observing its formation time, Indonesian coal is classified into the tertiary coal. Coal quality can be classified either based on the settings of the tectonic plates or its relationship to the geothermal gradient and tectonic stress [9]. In Indonesia, the coal quality is generally classified based on the setting of tectonic plates as given in Table 1 . Medium and low quality coal, dominate the reserves with a percentage of around $95 \%$. Low quality coal is mostly mined from Central Sumatra and South Sumatra basins. 


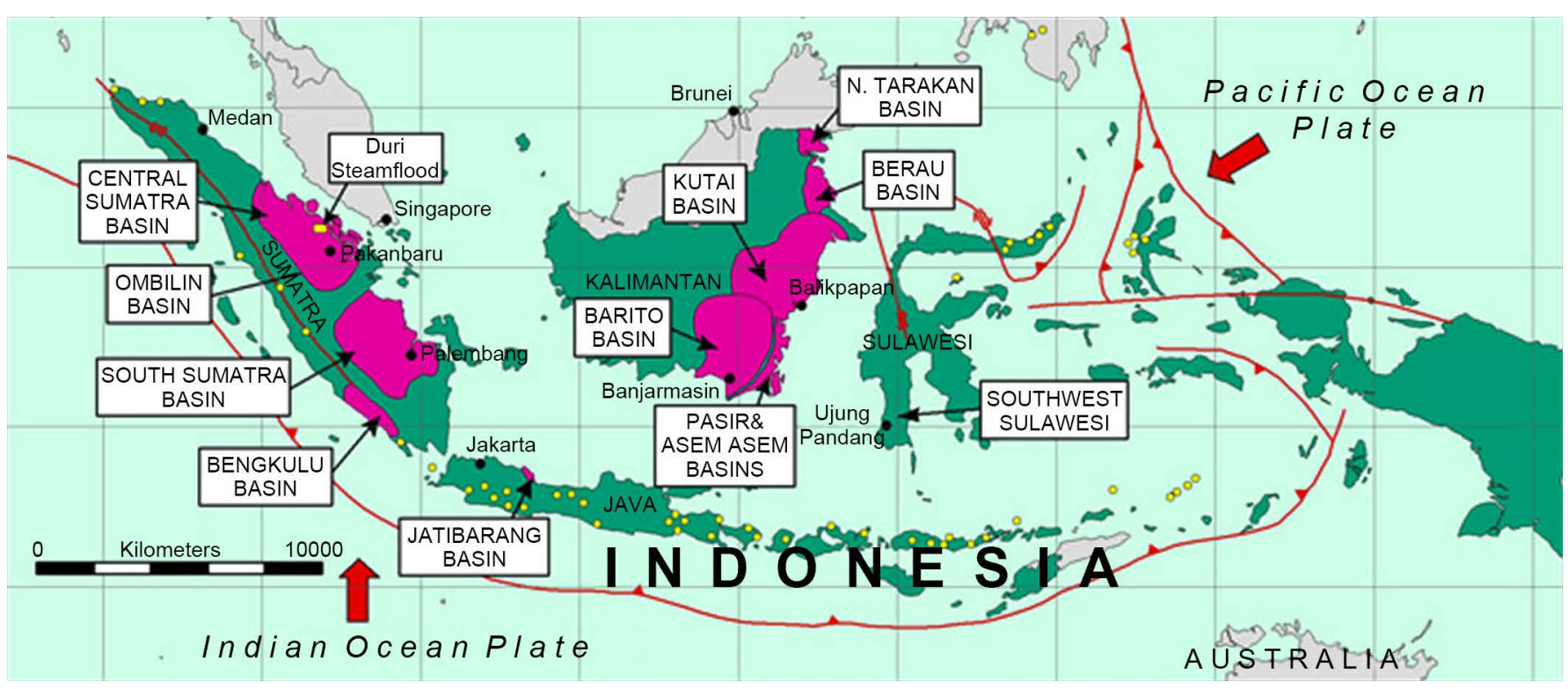

Source: CBM Asia Development Corp.

Figure 1. Distribution of coal basins in Indonesia.

Table 1. General quality of Indonesian coal based on setting of tectonic plates ${ }^{\mathrm{a}}$ [10].

\begin{tabular}{cccccc}
\hline Basin & Typical Deposit & $\begin{array}{c}\text { Calorific Value } \\
(\mathrm{KCal} / \mathrm{Kg})\end{array}$ & $\begin{array}{c}\text { Moisture } \\
\text { Content }^{\mathrm{b}}\end{array}$ & $\begin{array}{c}\text { Sulfur } \\
\text { Content }^{\mathrm{c}}\end{array}$ & $\begin{array}{c}\text { Ash } \\
\text { Content }^{\mathrm{d}}\end{array}$ \\
\hline Ombilin & $\begin{array}{c}\text { Lenticilar and small } \\
\text { coverage area } \\
\text { Thin and continuous } \\
\text { in lateral direction }\end{array}$ & 6000 & Low & How & Low \\
Barito-Tanjung \\
$\begin{array}{c}\text { Bengkulu } \\
\text { Centh Sumatra, } \\
\text { Barito-Warukin }\end{array}$ & $\begin{array}{c}\text { Thick and wide } \\
\text { coverage area }\end{array}$ & $<5000$ & High & Low & High \\
Kutai and Tarakan & & High & Low & High \\
\hline
\end{tabular}

Note: a General quality represent in as received (AR) basis; ${ }^{\mathrm{b}}$ Low moisture content is Total Moisture (TM) $<30 \%$ and High moisture content means TM $>30 \%$; ${ }^{~ L o w ~ s u l f u r ~ c o n t e n t ~ m e a n s ~ S u l f u r ~(S) ~}<1 \%$ and High sulfur content means $\mathrm{S}>1 \%$; ${ }^{\mathrm{d}}$ Low ash content means Ash $<10 \%$ and High ash content means Ash $>10 \%$.

\section{Production and Depletion of Indonesian Coal}

Coal production in Indonesia has started since the late 1800s in Ombilin and Mahakam coal fields. From the late 1800s until 1980s the coal production weren't much, mainly due to the lack competitiveness of coal in compare to oil as energy source. But the situation changed after the boom of the oil price in 1973. Many countries then started to look for an alternative energy source [11]. By then, coal becomes a substitute for petroleum and Indonesia becomes one of the coal exploration targets. Intensive exploration of coal resources in Indonesia was started since the first agreement of coal exploration and exploitation (Coal Contract of Work - CCOW) between P.N. Batubara as a repre- 
sentative of the Government of Indonesia (GoI) and PT. Arutmin Indonesia in 1981. Such an agreement was subsequently followed by other agreements between the P.N. Batubara with other 10 mining companies, 2 of them are national companies, in between 1981 to 1987.

The success of such coal exploration activities triggered coal production. The coal production was started since early 1990s when the mining companies of CCOW 1st generation started its production activity. The success of the first CCOW stimulates the establishment of the second and third CCOW in 1994 and 1997, respectively. Although they are not as successful as the first CCOW generation as not all the mining companies in second and third generations reached their production phase yet, all the three CCOWs provide significant impact on the Indonesia's coal production. In between 1990-2013, the coal production increased around 17\% per year (Figure 2) and the companies incorporated in CCoW contribute more than $60 \%$ of the total production.

When the coal production is classified based on its quality (Figure 2(b)), visible pattern of behavior in which the production of high quality coal is produced first compared to those of lower quality. Such a condition is shown in any coal basin. To analyze the behavior of the production of a non-renewable, exhaustible resource, depletion rate is used as an indicator to measure the reduction of reserves in a basin. Such an indicator is applicable to analyze the level of reserves reduction of coal, oil, natural gas, nickel, etc. [11].

Depletion rate is formulated as the inverse of R/P (Equation (1)). There are 2 types of depletion rate of non-renewable resource; depletion rate of the ultimate recoverable reserves (URR) and depletion rate of the remaining reserves. Depletion rate of URR analyzes part of which is produced annually. Meanwhile, the depletion rate of remaining reserve analyzes how fast the rest of the reserves will be depleted. The latter method is more widely used.

$$
d_{R R R, t}=\frac{q_{t}}{R_{r}}=\frac{q_{t}}{U R R_{t}-Q_{t}}
$$

Note

- $d_{R R R, t}=$ depletion of the remaining reserves

- $q_{t}=$ production in year

- $R_{r}=$ remaining reserves

- $U R R_{t}=$ ultimate recoverable reserves in year $t$

- $Q_{t}=$ cumulative production in year $t$

The depletion rate is influenced by physical, technical, and economical factors. In the case of petroleum, its depletion rate is influenced by fluid flow. Of many determinant factors of fluid flow, i.e. pressure, rock compressibility, dissolution, formation slope, capillarity, and more, the reservoir pressure and water influx are the two most dominant factors which influence the depletion rate of petroleum. The investigation of the depletion rate of productions of some nonrenewable resources shows that the maximum depletion rate generally occurs when the production reaches its peak point or the end of the plateau, after which the depletion rate will be stable or else lower [12]. 


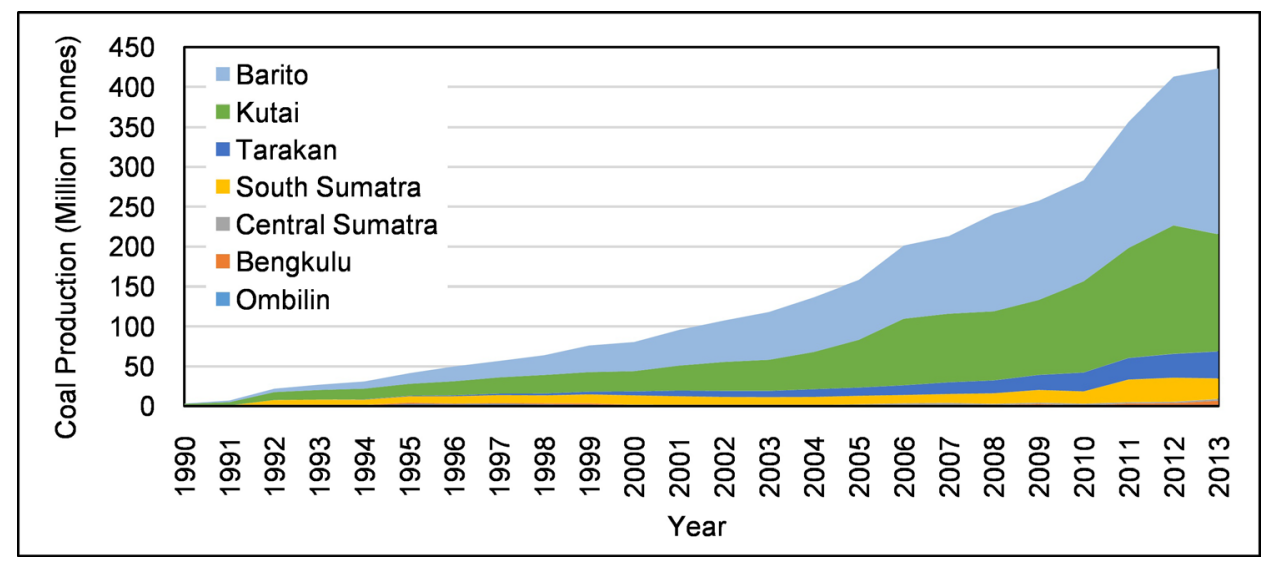

(a)

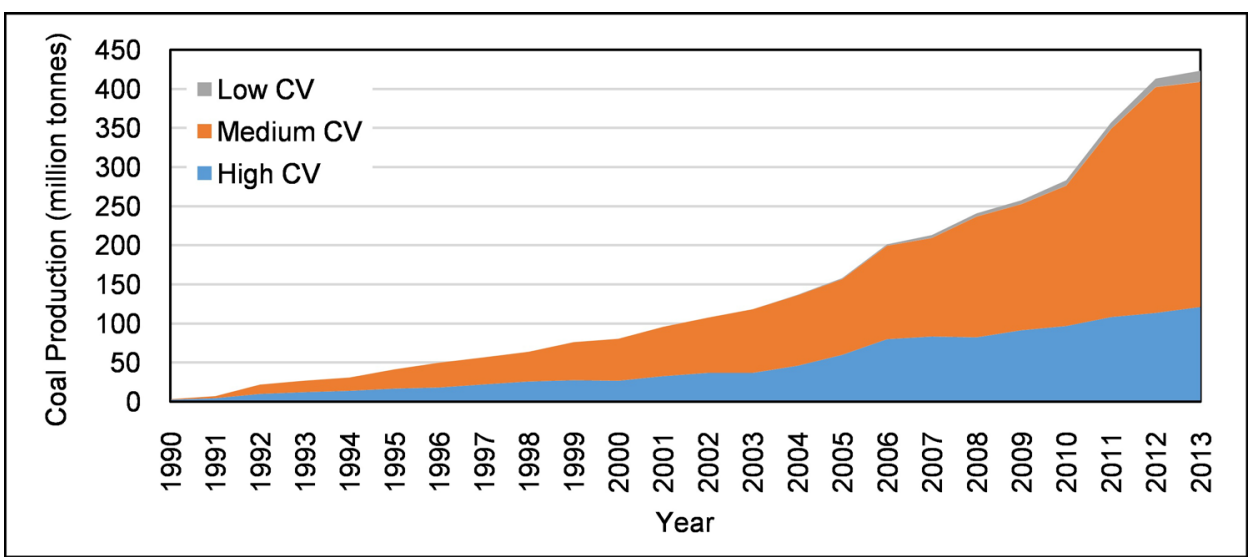

(b)

Figure 2. Distribution of coal basins in Indonesia. (a) Coal Production by Basin; (b) Coal Production by Quality. Note: Low CV (<5100 Kkal/Kg), medium CV (5100 - $6100 \mathrm{Kkal} / \mathrm{Kg})$, High CV $(>6100)$.

In the case of coal in Indonesia, the depletion rate is influenced by the quality of the coal in each coal basin (Table 2). The coal basin having a greater amount of high CV coal has higher depletion rate. Likewise, coal basin with a greater amount of low CV coal has smaller depletion rate. Anomaly condition occurs in Ombilin basin. Despite its high CV coal content, its depletion rate is low. This may be because the application of underground mine in Ombilin basin which require higher operating costs than the open pit operation in other basins.

\section{Forecasting of Coal Production}

Production of coal, like other non-renewable resources, is influenced by many factors. Factors affecting the production capacity of coal are the availability of reserves, the demand/market, and the development of technology on exploration, mining, and processing. In addition to the aforementioned physical factors, there are also considerations with respect to economic, social, and environmental aspects which influence the coal production. 
Table 2. Depletion rate in each Indonesian coal basin.

\begin{tabular}{|c|c|c|c|c|c|c|}
\hline \multirow{2}{*}{ Basin } & \multirow{2}{*}{$\begin{array}{l}\text { Remaining Reserve } \\
\text { (Million Tonnes) }\end{array}$} & \multicolumn{3}{|c|}{ Proportion of Reserves } & \multirow{2}{*}{$\begin{array}{c}\text { Production } \\
\text { (Million Tonnes) }\end{array}$} & \multirow{2}{*}{$\begin{array}{l}\text { Depletion } \\
\text { Rate }\end{array}$} \\
\hline & & Low CV & Med CV & $>$ High CV & & \\
\hline Ombilin & 158 & $0 \%$ & $2 \%$ & $98 \%$ & 0.5 & $0.7 \%$ \\
\hline Bengkulu & 19 & $0 \%$ & $20 \%$ & $80 \%$ & 6.8 & $6.8 \%$ \\
\hline Central Sumatra & 689 & $90 \%$ & $4 \%$ & $6 \%$ & 2.3 & $0.3 \%$ \\
\hline South Sumatra & 12,428 & $54 \%$ & $45 \%$ & $1 \%$ & 25.8 & $0.2 \%$ \\
\hline Kutai and Tarakan & 14,015 & $9 \%$ & $86 \%$ & $5 \%$ & 178.8 & $1.3 \%$ \\
\hline Barito & 4772 & $17 \%$ & $66 \%$ & $17 \%$ & 207.8 & $4.4 \%$ \\
\hline
\end{tabular}

The influencing factors of production, be it all or some, need to be considered to determine the production forecasting method. The most commonly used method in forecasting the coal production is Growth curve. The growth curve, be it Logistic, Gompertz, or Richard curve, assumes that the influencing factors of production are accumulated into the production behavior of such non-renewable resources. Thus, the extrapolation of the growth curve for the coming period will also accommodate the influencing factor of production [13]. A method of forecasting the coal production was also proposed by Mohr in 2009 by taking into account the interaction between supply and demand in which the coal supply is a function of demand [6]. Another production forecasting method is a dynamic system. Dynamic system model is formed by many sub-models which are interconnected, be it positive or negative correlation, and are a function of time. An example of sub-models components interconnected to build the dynamic coal supply model is economic development-coal demand-coal productionenvironmental pollution load [14].

In this study, the forecasting of Indonesian coal production will be carried out using Gompertz curve. This method assumes that the influencing factors have no significant change throughout the duration of the forecasting period. Thus, in the model such factors remain constant with respect to time. This method is generally used for short term forecasting.

$$
y(t)=U R R \times \mathrm{e}^{-k e^{-k\left(t-t_{0}\right)}}
$$

Note

- $y(t)$ : Cumulative production in time function $t$

- URR: Ultimate Recoverable Reserves

- $k$. Constant

- $t-t_{0}$ : Duration of forecast

Gompertz curve predicts the production based on previous time series data of the cumulative production. The data will be smoothed with respect to Equation 2. Iteration process is required to determine $\mathrm{k}$, constant of the equation. Production forecasting is carried out by extrapolating the graph by assuming constant URR and single-peak 
curve. The curve will reach its maximum point (peak production) when the coal reserve is depleted of around $37 \%$ of the total URR [13]. Thus it makes this curve asymmetric and skewed to the right.

Equation (2) of Gompertz curve indicates that the cumulative production value of $y(t)$ will only depend on URR value. Thus, the accuracy of URR will determine the accuracy of the coal production forecasting. The URR can be determined through two approaches, i.e. quoted reserves and production history based in reserves. Quoted reserves are estimated based on official data issued by an official institution. Meanwhile URR based on production history is analyzed and determined based on historical data of production such as Hubbert linearization Process [15].

Debate often arises in deciding which type of URR is more realistic as an input of production forecasting. URR of quoted reserves refers to the total reserves, both the economical reserves in current time and the reserves that will be mined in future. In other words, URR of the quoted reserves refers to the maximum reserve. URR of production history, in other hand, estimates the reserve based on current condition. It refers only to the economical reserves in current time.

In this study, the URR is determined based on the quoted reserves acquired from the Geological Agency, Indonesian Ministry of Energy and Mineral Resources. Quoted reserves approach is chosen to study the long-term effects of the availability of reserves and coal production with respect to the extraction cost. URR values of the Indonesian coal basins are listed in Table 3.

By using historical data of coal production from 1990 to 2013, URR quoted reserves (Table 3), and the general equation of Gompertz curve (Equation (2)), Indonesian coal production forecasting results are acquired and listed in Table 4 . The results show that Indonesia's coal production will reach its peak in 2026 with the production of around 485 million tones (Figure 3). The Kalimantan coal basins, Kutai, Barito, and Tarakan Basins, continue to provide the most contribution to Indonesian coal production until

Table 3. URR quoted reserves on forecasting the Indonesian coal production [23].

\begin{tabular}{cccc}
\hline Coal Basin & $\begin{array}{c}\text { Remaining } \\
\text { Reserve in 2013 } \\
\text { (Million Tonnes) }\end{array}$ & $\begin{array}{c}\text { Cumulative } \\
\text { Production } \\
\text { (Million Tonnes) }\end{array}$ & $\begin{array}{c}\text { Total URR } \\
\text { (Million Tonnes) }\end{array}$ \\
\hline Ombilin & 158.4 & 23.2 & 181.6 \\
Bengkulu & 18.9 & 26.4 & 45.4 \\
Central Sumatra & 689.2 & 16.7 & 705.9 \\
South Sumatra & 12,428 & 285.7 & 12,713 \\
Tarakan & 1261 & 233.8 & 1495 \\
Kutai & 12,029 & 1270 & 6353 \\
Barito & 4771 & 1585 & 34,798 \\
Total & 31,357 & 3441 & \\
\hline
\end{tabular}


Table 4. Result of forecasting of Indonesian coal production by Gompertz curve.

\begin{tabular}{|c|c|c|c|c|}
\hline Basin & $\begin{array}{c}\text { Gompertz curve } \\
\text { Equation }\end{array}$ & Peak year & $\begin{array}{l}\text { Peak Production } \\
\text { (million tonnes) }\end{array}$ & $\begin{array}{c}\text { Depletion rate } \\
\text { at peak }\end{array}$ \\
\hline Ombilin & $y(t)=182 \mathrm{e}^{-4.07 \mathrm{e}^{-0.024\left(t-t_{0}\right)}}$ & 2048 & 1.6 & $1.40 \%$ \\
\hline Bengkulu & $y(t)=45 \mathrm{e}^{-4.6 \mathrm{e}^{-0.072(t-0)}}$ & 2011 & 1.2 & $4.33 \%$ \\
\hline Central Sumatra & $y(t)=706 \mathrm{e}^{-11.9 \mathrm{e}^{-0.099\left(t-t_{0}\right)}}$ & 2040 & 12.7 & $2.88 \%$ \\
\hline South Sumatra & $y(t)=12,714 \mathrm{e}^{-6.75 \mathrm{e}^{-0.024(-1-0)}}$ & 2069 & 111.6 & $1.39 \%$ \\
\hline Tarakan & $y(t)=1495 \mathrm{e}^{-10.1 e^{-0.07(t-1-0)}}$ & 2023 & 38.5 & $4.24 \%$ \\
\hline Kutai & $y(t)=13,299 \mathrm{e}^{-7.75 \mathrm{e}^{-0.05\left(t-t_{0}\right)}}$ & 2031 & 241.7 & $2.92 \%$ \\
\hline Barito & $y(t)=6353 \mathrm{e}^{-8.5 \mathrm{e}^{-0.74(t-10)}}$ & 2018 & 173.4 & $4.35 \%$ \\
\hline Indonesia & & 2026 & 485.4 & $1.89 \%$ \\
\hline
\end{tabular}

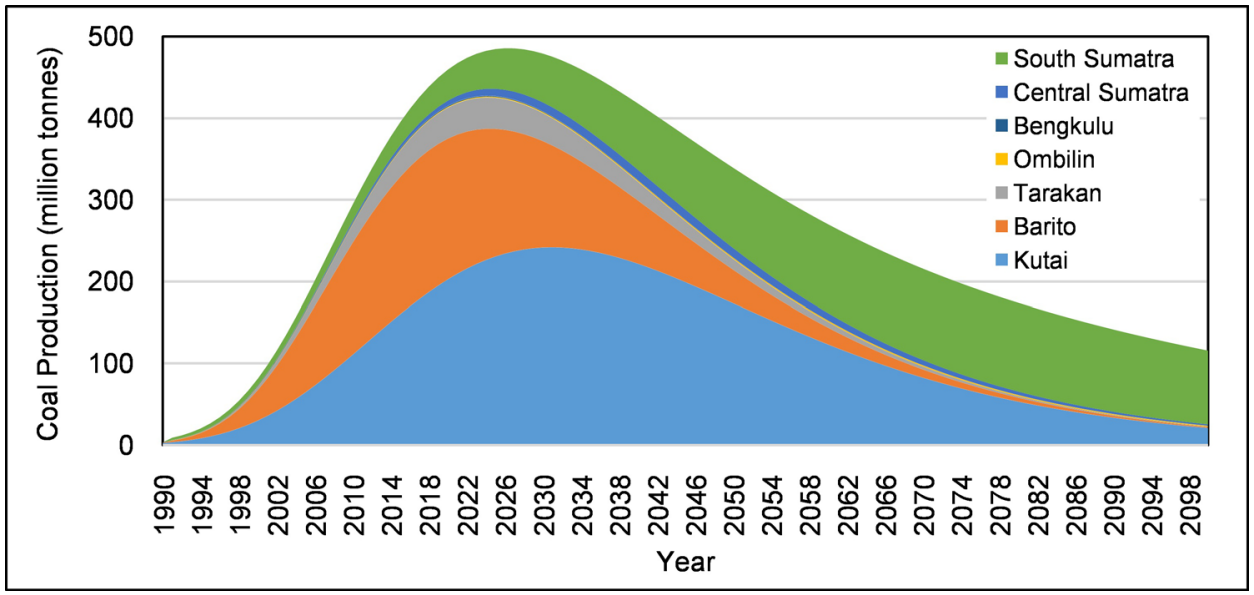

Figure 3. Forecasting of Indonesian coal production to 2100.

2065. Indonesia's coal production relies heavily on these three coal basins of Kaliman$\tan$ Island. The decline in production from these Kalimantan basins from 2024 cannot be replaced by the production from the Sumatran basins due to its superiority. Kalimantan coal is preferred by consumers due to its high calorific value, closer location to the consumer and the ease of transportation (by the river and its infrastructure that supports large quantity production).

Depletion rate analysis is performed to examine the reasonability of the forecasting results. Data of the maximum depletion rate of other non-renewable resources is gathered. It includes the US copper production of 4.3\%, South African gold production of $4.1 \%$, and US coal production of about 3\% [16] [17] [18]. Wallan (2014) in his study states that the maximum depletion rate is about 5\% [19]. In this forecasting study using the Gompertz curve, the depletion rates at the peak production are given in Table 4. The highest is observed in the Barito basin at $4.4 \%$ and it is less than $5 \%$. This may be concluded that the obtained forecasting production results are reasonable. 


\section{Forecasting of Indonesian Coal Operating Cost}

\subsection{Operating Cost and Cumulative Production}

One of the main components in production of coal and mineral resources is the extraction cost whose value is equivalent to the operating cost. The operating cost tends to increase as the reserves decrease. This phenomenon, according to Hotelling (1931), occurs as people/community will mine/extract a resource of low operating cost before switching to other resources with higher operating cost [20] [21]. Mineral ores of higher grade, for example, will be extracted first and bypass the lower grade ores or delay their extraction as higher grade ores possess lower processing cost due to lower energy consumption. Similarly in the case of coal, reserves located on or near to the surface will be mined first than those located deeper underground due to lower operating costs. The long-term operating cost may later be descending or increase as function of the grades of the later mined coal reserves as well as the technological development in mining and processing.

Herein, the analysis of the correlation between the cumulative production and operating cost in Indonesian coal mining will be conducted for three coal mining companies, i.e. PT Adaro Indonesia (Adaro), PT Arutmin Indonesia (Arutmin), and PT Kaltim Prima Coal (KPC). They are sufficiently representative as their productions are approximately $30 \%$ of total coal production in Indonesia. The cumulative production data and operating cost at the three companies are plotted in Figure 5. The operating cost covers 4 components of cost, i.e. extraction cost and overburden, processing cost, transportation cost, and royalty.

Cumulative production and operating cost in Indonesian coal mining, like other non-renewable resources, shows similar trend in which the production cost will increase along with the increase of the cumulative production. The cumulative data from the three mining companies shows that within 10 years the operating cost increased by an average of $10 \%$ per year while production increased by $9.3 \%$ per year.

The operating cost in Indonesian coal mining increases primarily due to the increase in the stripping ratio (SR) (Figure 4). The increase of annual production requires the mining companies to expand or deepen the size of the mining pit, which in turn will increase the SR per year. With a relatively constant value of operating costs per SR (USD/t/bcm) of around USD 4.02 per ton.bcm, the increment of SR will therefore be the main determinant of the operating cost.

In terms of the operating cost per stripping ratio, the three coal mining companies have varying costs. Adaro's cost per stripping ratio is the largest among the three, of USD 6.15 per ton, followed by Arutmin 3.39 USD per ton, and t KPC 3.17 USD per ton. The difference in the operating cost of these companies is due to different supply chain production. Adaro requires greater cost as it needs to transport coal from the mine to the selling point as far as $200 \mathrm{Km}$ using barges. KPC experiences the lowest cost as its mine site is adjacent to the beach. Thus, it only requires an overland conveyor to load the coal onto barges or ships before being transported to the consumer. 


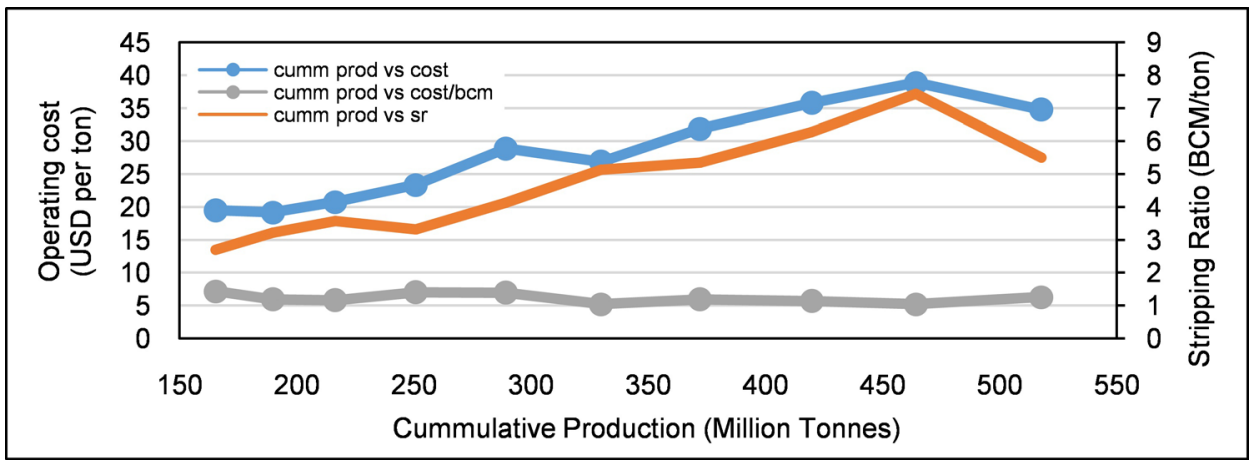

(a)

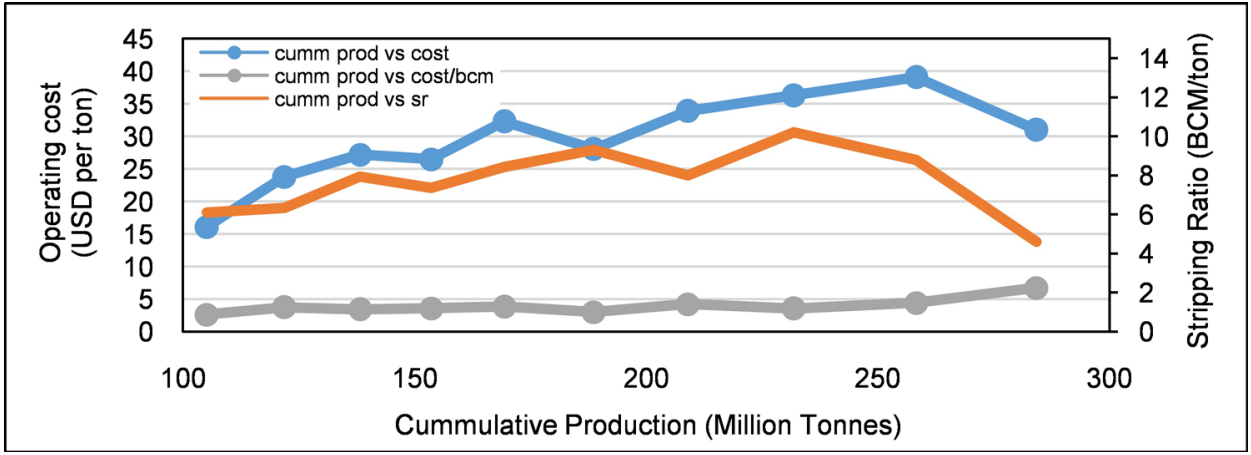

(b)

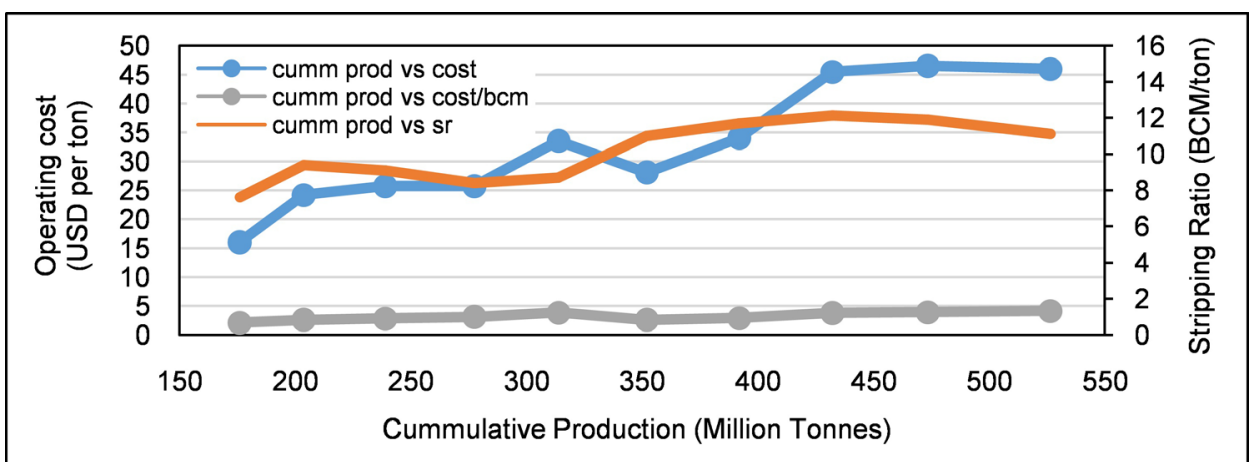

(c)

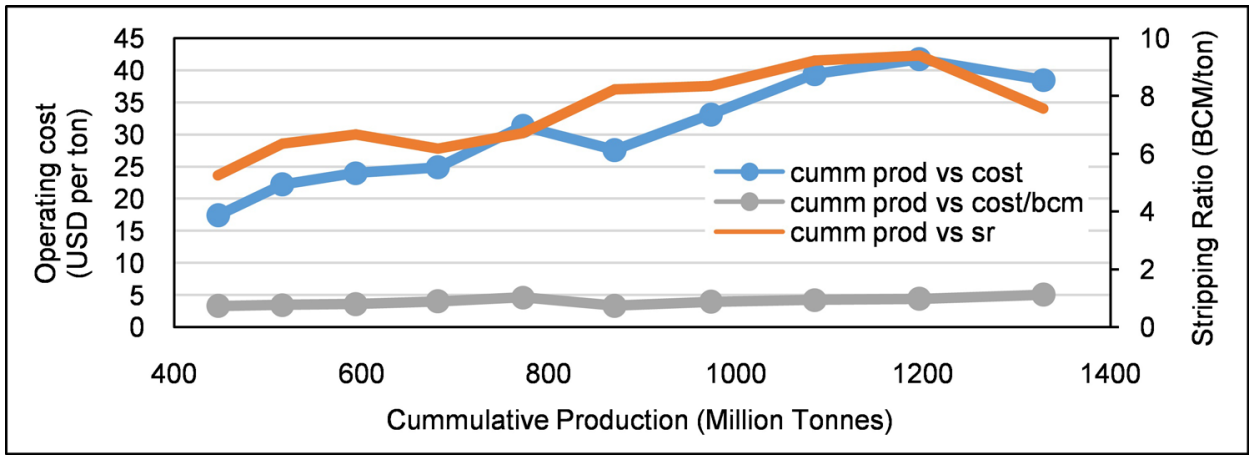

(d)

Figure 4. Cumulative production and operating cost for Indonesian coal mine. (a) Adaro Indonesia; (b) Arutmin Indonesia; (c) Kaltim Prima Coal; (d) Cumulative for three mining companies. 
In 2012 there were more than $900 \mathrm{coal}$ mining licenses in Indonesia [22]. Coal mining spreads around Kalimantan and Sumatra islands. The dispersed locations of the mining operations cause the variation in supply chain and the operating cost. It may not be possible to collect data from all the Indonesian coal mines. Thus, as an illustration of the operating cost of the Indonesian coal mines, the supply curve of Indonesian coal obtained from 9 Indonesian coal mining companies whose total production accounted for around 50\% of the total national production is plotted in Figure 5. The operating cost of Indonesian coal mine, excluding royalties, cost of sales and general and administrative expenses, during the years of 2011 to 2013 is in between USD 39 42 per ton.

\subsection{Model and Forecasting of Operating Cost of Indonesian Coal Mine}

Model of coal mine operating cost is developed with the assumption that the cost will increase as the cumulative production increases. The increase in the operating cost with respect to the cumulative production forms particularly similar trend as long as there is no significant change in the condition of mineable reserves, such like the change in the mining method from the open pit mining into underground mining.

In the case of Indonesia, the operating cost model is developed in every economic coal basin. The steps to formulate operating cost model are as follows; 1 ) determine the operating cost based on the gross profit margin, 2) plotting the historical data of the average operating cost and the cumulative production, 3) trend analysis to smoothing the cumulative availability curve.

Gross profit margin approach is chosen in estimating the operating cost as it enables operating cost data collection of all the Indonesian coal mines. Gross profit margin is the profit value after the deduction of cost of goods sold (mining, processing, and transportation costs) and royalty. The average values of the gross profit margin with respect to the coal basin of period 1998 to 2013 are listed in Table 5.

By knowing the profit portion from the gross profit margin, the operating cost is determined as the difference between the revenue and the profit. Revenue earned from

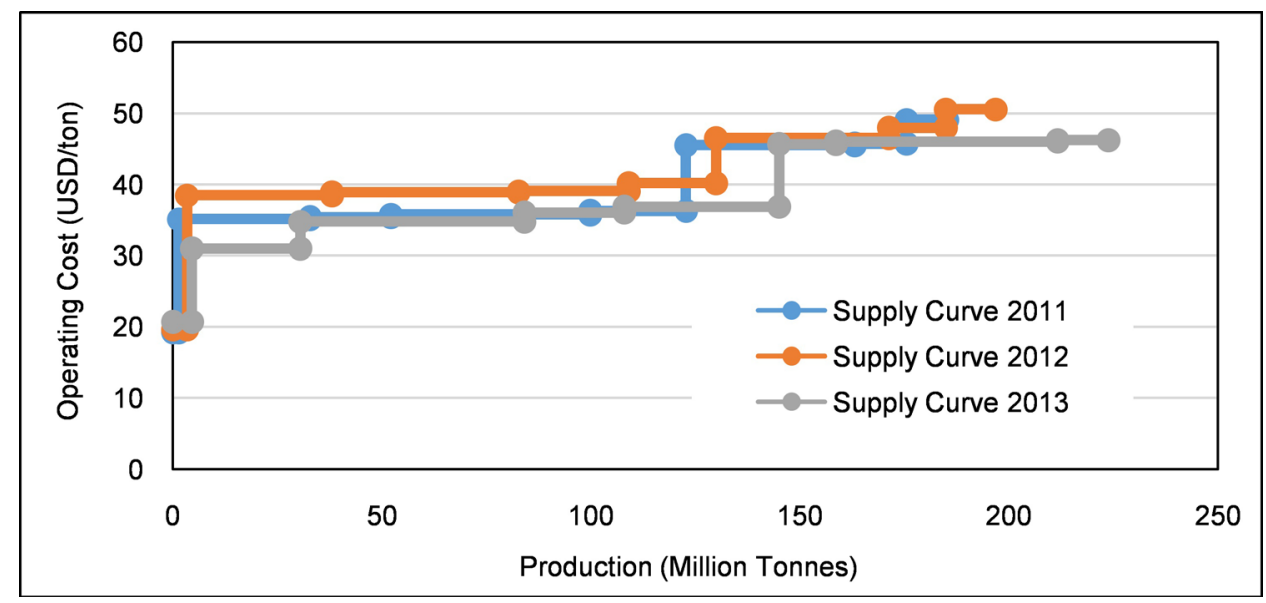

Figure 5. Supply curve for Indonesian coal. 
Table 5. The average operating cost of the coal basins [23]-[34].

\begin{tabular}{|c|c|c|c|c|c|c|c|c|c|c|c|c|c|c|c|c|c|}
\hline Basin & Component & 1998 & 1999 & 2000 & 2001 & 2002 & 2003 & 2004 & 2005 & 2006 & 2007 & 2008 & 2009 & 2010 & 2011 & 2012 & 2013 \\
\hline & Price reference ${ }^{\mathrm{a}}$ & 20.7 & 19.1 & 23.0 & 28.2 & 21.7 & 27.8 & 63.7 & 53.1 & 47.7 & 75.8 & 139.3 & 70.1 & 96.7 & 117.0 & 96.8 & 82.2 \\
\hline \multirow{5}{*}{ Ombilin } & Average production $\mathrm{CV}^{\mathrm{b}}$ & 6612 & 6497 & 6418 & 6448 & 6512 & 6705 & 6859 & 6663 & 6593 & 6961 & 6332 & 6300 & 6304 & 6500 & 6500 & \\
\hline & Price estimated $^{c}$ & 29.5 & 27.4 & 30.9 & 36.0 & 30.0 & 37.1 & 75.3 & 62.4 & 56.4 & 89.2 & 142.0 & 75.2 & 100.7 & 123.8 & 103.9 & \\
\hline & & & & & & & & & & & & & & & & & \\
\hline & Average gross profit margin & $39 \%$ & $39 \%$ & $39 \%$ & $39 \%$ & $39 \%$ & $39 \%$ & $34 \%$ & $28 \%$ & $23 \%$ & $28 \%$ & $36 \%$ & $39 \%$ & $37 \%$ & $42 \%$ & $33 \%$ & \\
\hline & Average operating $\operatorname{cost}^{\mathrm{d}}$ & 18.1 & 16.8 & 18.9 & 22.1 & 18.4 & 22.7 & 49.7 & 44.9 & 43.5 & 64.6 & 91.5 & 45.6 & 63.7 & 71.4 & 70.1 & \\
\hline \multirow{5}{*}{ Bengkulu } & Average production $\mathrm{CV}$ & 6234 & 6193 & 6190 & 6154 & 6222 & 6356 & 6385 & 6442 & 6509 & 6351 & 6300 & 6320 & 6358 & 6248 & 6249 & 6300 \\
\hline & Price estimated & 19.6 & 17.9 & 21.6 & 26.3 & 20.4 & 26.8 & 61.6 & 51.8 & 47.1 & 73.0 & 133.0 & 67.1 & 93.1 & 110.8 & 91.6 & 78.4 \\
\hline & & & & & & & & & & & & & & & & & \\
\hline & Average gross profit margin & $39 \%$ & $39 \%$ & $39 \%$ & $39 \%$ & $39 \%$ & $39 \%$ & $34 \%$ & $28 \%$ & $23 \%$ & $28 \%$ & $36 \%$ & $39 \%$ & $37 \%$ & $42 \%$ & $33 \%$ & $26 \%$ \\
\hline & Average operating cost & 12.0 & 11.0 & 13.2 & 16.1 & 12.5 & 16.4 & 40.7 & 37.2 & 36.3 & 52.9 & 85.7 & 40.7 & 58.9 & 63.9 & 61.8 & 58.4 \\
\hline \multirow{4}{*}{$\begin{array}{l}\text { Central } \\
\text { Sumatra }\end{array}$} & Average production $\mathrm{CV}$ & & & & & & & 5594 & 5537 & 5581 & 5349 & 5304 & 5779 & 5917 & 5941 & 5653 & 5663 \\
\hline & Price estimated & & & & & & & 61.4 & 51.9 & 47.8 & 68.5 & 119.0 & 69.0 & 94.5 & 113.2 & 90.4 & 78.0 \\
\hline & Average gross profit margin & & & & & & & $34 \%$ & $28 \%$ & $23 \%$ & $28 \%$ & $36 \%$ & $39 \%$ & $37 \%$ & $42 \%$ & $33 \%$ & $26 \%$ \\
\hline & Average operating cost & & & & & & & 40.6 & 37.3 & 36.8 & 49.7 & 76.7 & 41.8 & 59.8 & 65.3 & 60.9 & 58.1 \\
\hline \multirow{4}{*}{$\begin{array}{c}\text { South } \\
\text { Sumatra }\end{array}$} & Average production $\mathrm{CV}$ & 5900 & 5900 & 5900 & 5926 & 5931 & 5928 & 5933 & 5931 & 5932 & 5926 & 5923 & 5885 & 5914 & 5767 & 5756 & 5768 \\
\hline & Price estimated & 19.6 & 18.1 & 21.8 & 26.7 & 20.5 & 26.3 & 60.3 & 50.3 & 45.2 & 71.9 & 130.7 & 65.0 & 90.6 & 104.9 & 86.7 & 74.1 \\
\hline & Average gross profit margin & $39 \%$ & $39 \%$ & $39 \%$ & $39 \%$ & $39 \%$ & $39 \%$ & $40 \%$ & $39 \%$ & $38 \%$ & $40 \%$ & $49 \%$ & $54 \%$ & $46 \%$ & $50 \%$ & $44 \%$ & $31 \%$ \\
\hline & Average operating cost & 12.0 & 11.1 & 13.4 & 16.4 & 12.6 & 16.1 & 36.3 & 30.9 & 28.1 & 43.1 & 66.8 & 29.8 & 48.7 & 52.5 & 48.6 & 51.1 \\
\hline \multirow{5}{*}{ Tarakan } & Average production $\mathrm{CV}$ & 5544 & 5537 & 5518 & 5534 & 5548 & 5534 & 5469 & 5453 & 5480 & 5503 & 5495 & 5519 & 5518 & 5523 & 5465 & 5378 \\
\hline & Price estimated & 17.4 & 16.0 & 19.3 & 23.6 & 18.2 & 23.3 & 52.8 & 43.9 & 39.6 & 63.2 & 116.0 & 58.6 & 80.9 & 97.9 & 80.1 & 67.0 \\
\hline & & & & & & & & & & & & & & & & & \\
\hline & Average gross profit margin & $39 \%$ & $39 \%$ & $39 \%$ & $39 \%$ & $39 \%$ & $39 \%$ & $32 \%$ & $26 \%$ & $21 \%$ & $26 \%$ & $34 \%$ & $41 \%$ & $35 \%$ & $42 \%$ & $33 \%$ & $24 \%$ \\
\hline & Average operating cost & 10.7 & 9.8 & 11.8 & 14.5 & 11.2 & 14.3 & 35.9 & 32.4 & 31.4 & 46.9 & 76.9 & 34.7 & 52.6 & 56.8 & 53.7 & 50.9 \\
\hline \multirow{4}{*}{ Kutai } & Average production $\mathrm{CV}$ & 6214 & 6228 & 6225 & 6222 & 6218 & 6218 & 6254 & 6270 & 6256 & 6212 & 6166 & 6164 & 6101 & 6039 & 6012 & 6071 \\
\hline & Price estimated & 19.5 & 18.0 & 21.7 & 26.5 & 20.4 & 26.2 & 60.4 & 50.5 & 45.3 & 71.4 & 130.2 & 65.4 & 89.4 & 107.1 & 88.2 & 75.6 \\
\hline & Average gross profit margin & $39 \%$ & $39 \%$ & $39 \%$ & $39 \%$ & $39 \%$ & $39 \%$ & $33 \%$ & $33 \%$ & $23 \%$ & $26 \%$ & $31 \%$ & $33 \%$ & $33 \%$ & $37 \%$ & $27 \%$ & $21 \%$ \\
\hline & Average operating cost & 12.0 & 11.0 & 13.3 & 16.3 & 12.5 & 16.1 & 40.2 & 34.0 & 35.0 & 52.6 & 89.3 & 43.8 & 59.7 & 67.5 & 64.5 & 59.7 \\
\hline \multirow{5}{*}{ Barito } & Average production $\mathrm{CV}$ & 5533 & 5530 & 5545 & 5535 & 5544 & 5525 & 5543 & 5566 & 5576 & 5592 & 5597 & 5593 & 5626 & 5650 & 5640 & 5635 \\
\hline & Price estimated & 17.4 & 16.0 & 19.3 & 23.6 & 18.2 & 23.3 & 53.5 & 44.8 & 40.3 & 64.3 & 118.2 & 59.4 & 82.4 & 100.2 & 82.7 & 70.2 \\
\hline & & & & & & & & & & & & & & & & & \\
\hline & Average gross profit margin & $39 \%$ & $39 \%$ & $39 \%$ & $39 \%$ & $39 \%$ & $39 \%$ & $29 \%$ & $22 \%$ & $18 \%$ & $25 \%$ & $37 \%$ & $42 \%$ & $38 \%$ & $45 \%$ & $35 \%$ & $29 \%$ \\
\hline & Average operating cost & 10.7 & 9.8 & 11.9 & 14.5 & 11.2 & 14.3 & 38.0 & 35.1 & 33.0 & 48.1 & 74.8 & 34.7 & 50.8 & 55.0 & 53.9 & 49.8 \\
\hline
\end{tabular}


the coal sale is a function of coal quality and benchmark price. The benchmark price herein used as the basis of estimation is the Asian spot price index which is applicable for coal with calorific value of $6600 \mathrm{kcal} / \mathrm{kg}$ (adb). Table 5 shows the estimated average operating costs in every coal basins.

After plotting the data of the cumulative production and the estimated operating cost, trend analysis is then performed to determine the correlation between the two variables. Figure 6 shows the data plotting and the trend analysis of the cumulative production and operating costs in every coal basins. Logarithmic trend is selected as it has identical behavior with the cumulative availability curve of non-renewable resource whereby the reserves mined are relatively homogeneous.

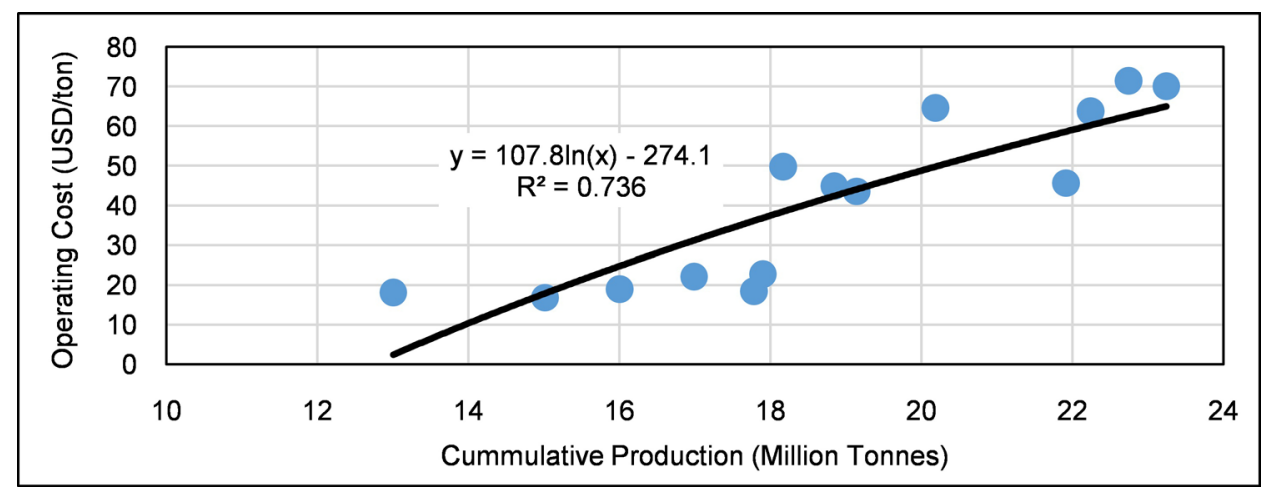

(a)

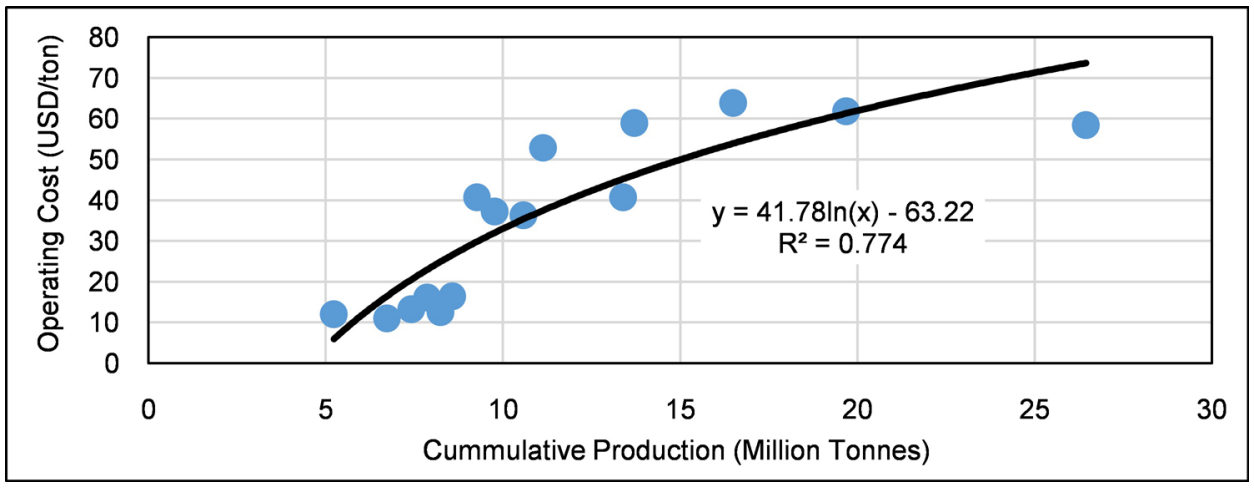

(b)

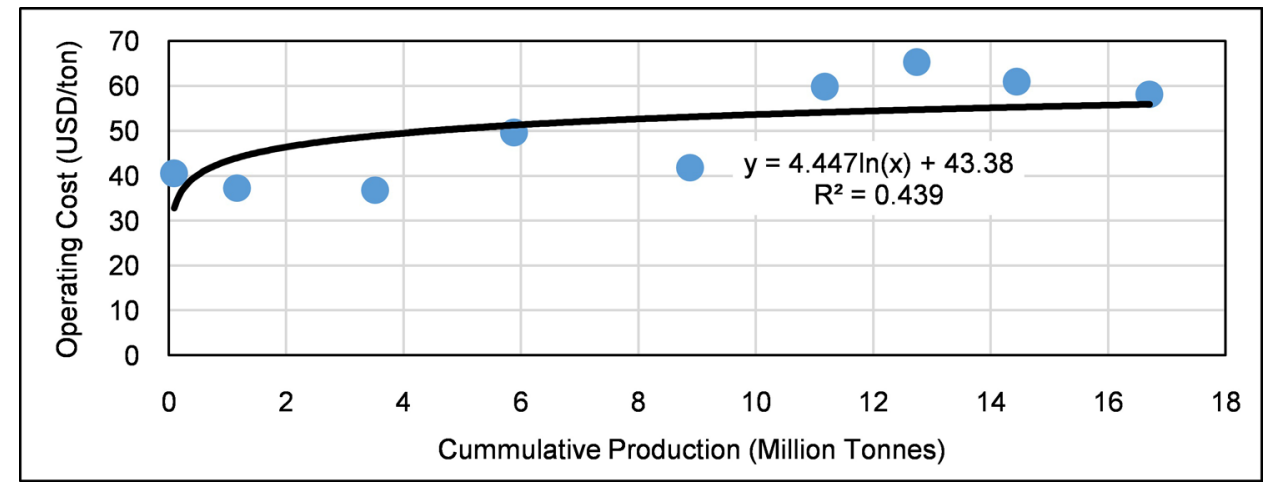

(c) 


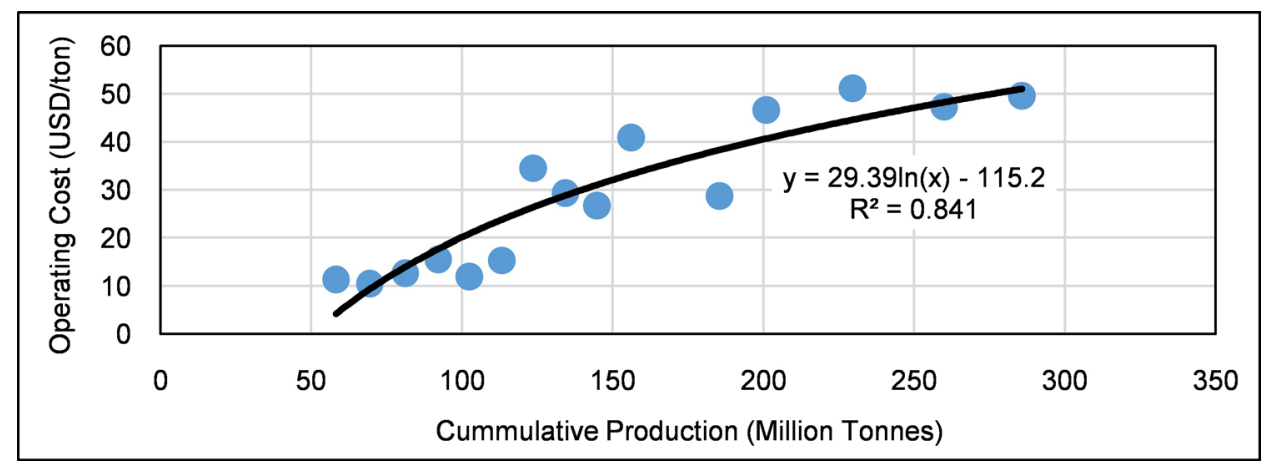

(d)

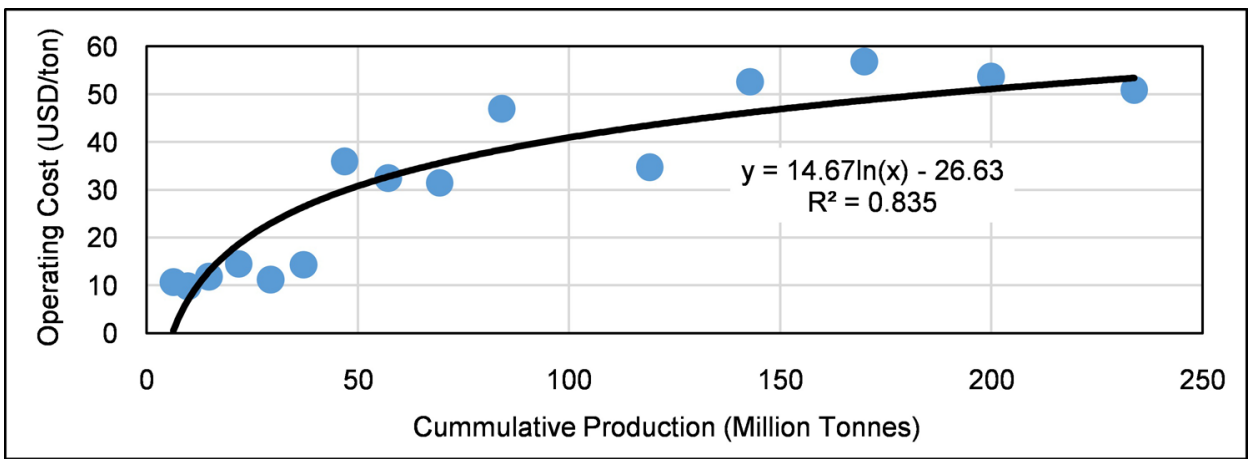

(e)

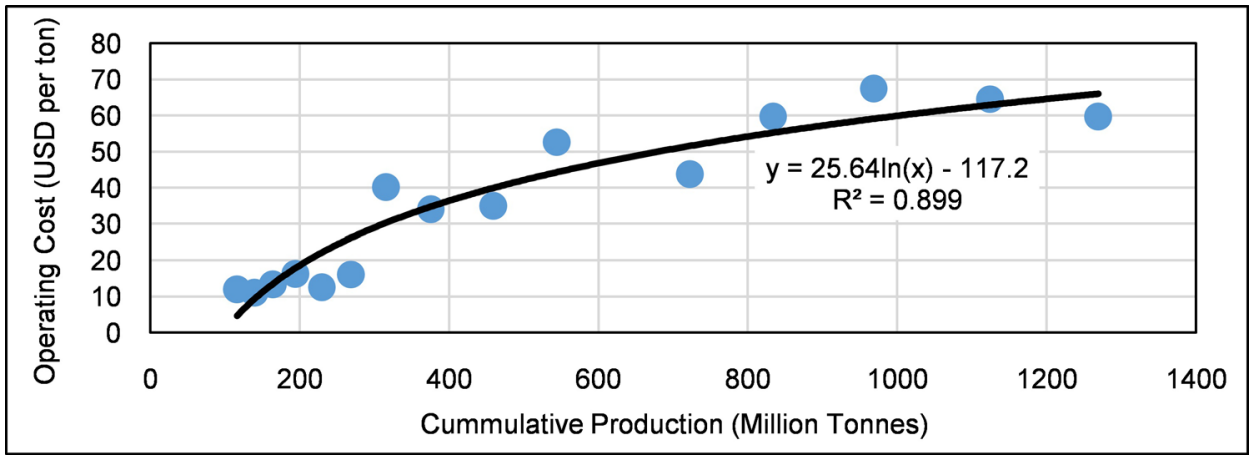

(f)

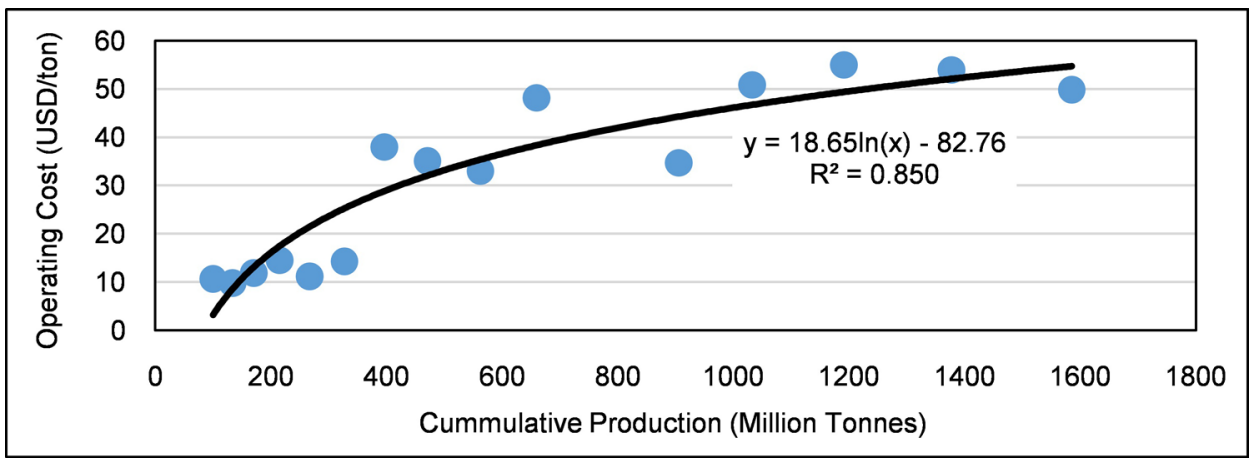

(g)

Figure 6. Model of Indonesian coal's operating cost. (a) Bengkulu Basin; (b) Ombilin Basin; (c) Central Sumatra Basin; (d) South Sumatra Basin; (e) Tarakan Basin; (f) Kutai Basin; (g) Barito Basin. 
The operating cost model is obtained as a function of the cumulative production. Such a model can therefore be used to predict the operating cost of the foreseeable future. Results obtained from forecasting the coal production of each basin using Gompertz curve as described in Section 3 will hereinafter be input on the operating cost model to obtain the estimated operating cost. Results of the estimated operating cost from 2014 to 2040 are plotted in Figure 7. Ombilin basin, among other basins, until 2040, requires the highest operating cost. This is reasonable due to the mining method applied in Ombilin basin is underground mines. Thus, it requires higher operating cost than other basins of open pit method. Central Sumatra basin, on the other hand, requires the smallest operating cost as it produces coal of low quality. Low quality coal is mined using low stripping ratio. Thus, it requires low operating costs.

\section{Discussion}

The results of production and operating cost forecasting may be used for greater purposes like coal policy analysis and prospect evaluation of the Indonesian coal sales in export market. Herein Domestic Market Obligation (DMO) policy is analyzed. Meanwhile, with respect to the prospect evaluation, herein the ability of Indonesian coal to compete in the export market will be observed in terms of the operating costs.

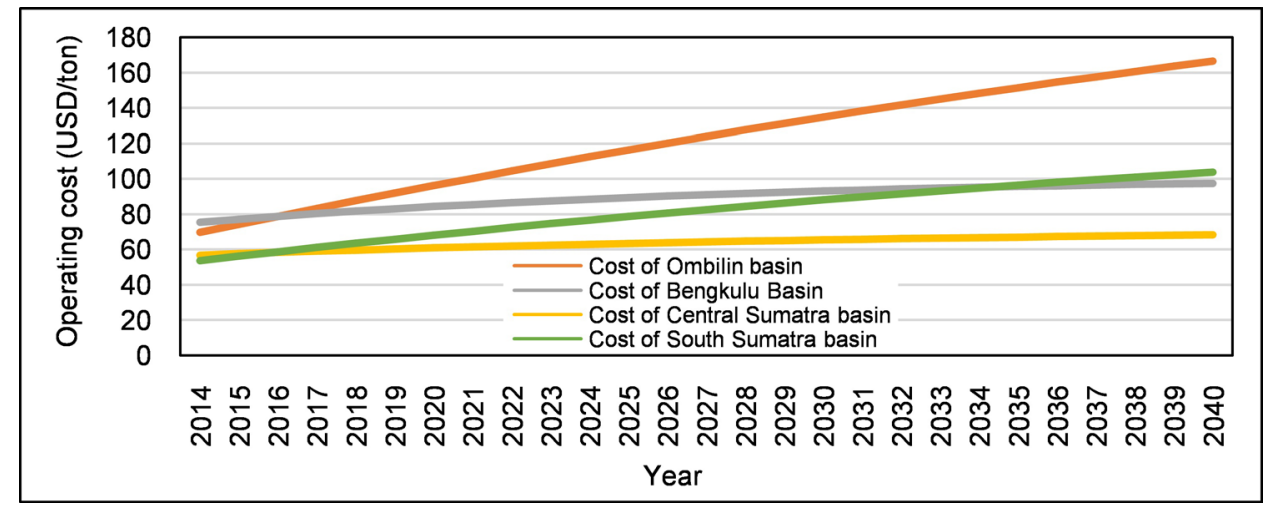

(a)

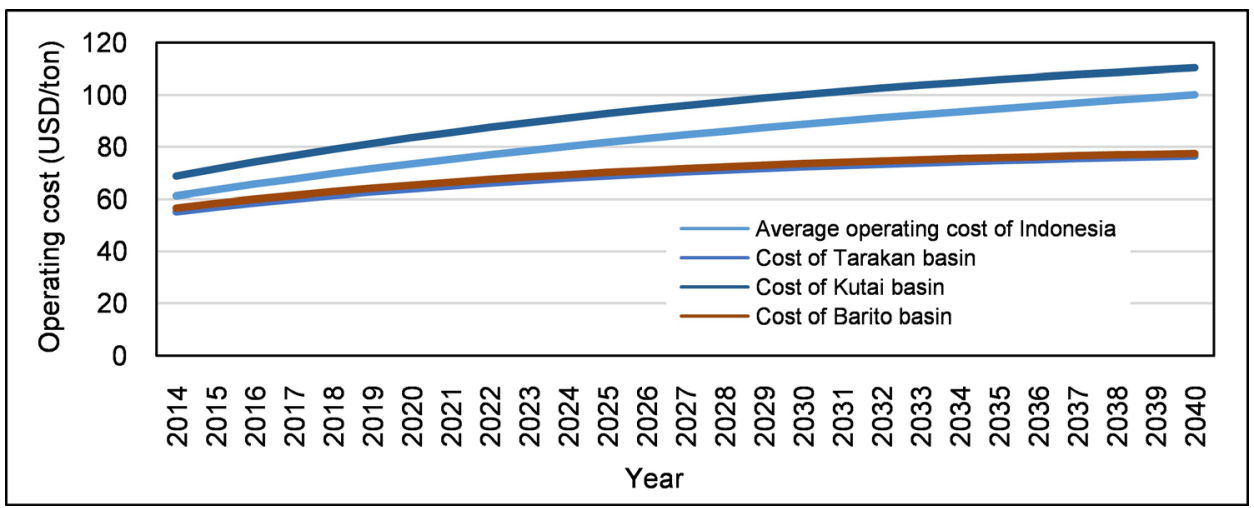

(b)

Figure 7. Forecasting the Indonesian coal mining operating cost. (a) Operating cost of coal basin in Sumatra; (b) Operating cost of coal basin in Kalimantan. 
DMO is the Indonesian government's policy which aims to ensure the continuity of coal supply in the domestic market. The policy is implemented by Decree of the Ministry of Energy and Mineral Resources (MEMR) No. 342009 on the priority of mineral and coal supply for domestic needs by setting up a minimum percentage of coal sales in the domestic market based on the estimated domestic consumption and future production. The quantity of domestic sales for each coal mining company will be determined based on the minimum percentage stated. Implementation of the DMO has faced many problems. One of the problems is consumer preference to choose producer who offers lowest price. Unfortunately, those producers may not be one of the mining companies listed in Ministerial Decree. The mining companies listed in Ministerial Decree may then be difficult to get domestic consumers due to their mining technique and mining location which will generate higher selling price.

Meanwhile, the evaluation of the coal sales prospect in the export market is carried out by estimating the supply cost and comparing it with the supply cost from other producing countries. The coal production is prioritized for the domestic supply. Once domestic needs are met, the rest of the production will be sold in the export market. As a result, the domestic consumers will get a lower price than the overseas consumers.

The main factor to decide the DMO policy analysis and the evaluation of sales prospect in the export market is the domestic coal demand. Currently, only about 20\% of Indonesia's coal production is consumed domestically. Much of the coal is consumed for the purpose of electricity generation and cement industry. In the future the increase in domestic coal consumption is led by the power plant sector. This increase is strongly affected by government policy to substitute oil-based power plants with coal-based power plants. Starting from 2006, PLN, the Indonesian state electric company, announced a 10,000 MW fast-track program to build 33 coal-fired power plants with total capacity of $9.48 \mathrm{GW}$.

PLN and BPPT, the State Electricity Company and the Agency for Assessment and Application of Technology of Indonesia, have been forecasting the coal demand in the domestic market. PLN, in its electricity supply plan of 2015 to 2024, estimated in 2024 Indonesian coal demand for power plant coal supply of around 171 million tonnes [35]. BPPT, on the other hand, Indonesian estimated coal demand until 2035 by assuming that growth in coal consumption for electricity generation would increase is by an average of $8.2 \%$ per year and for the industry by $7.4 \%$ per year [36]. In addition, there is additional demand for coal producing coal to liquid (CTL), which is due to begin in 2030. Such coal demand is expected to be around 4.5 million tonnes per year. Summarizing Reviews These assumptions, the estimated total Indonesian coal consumption in 2035 is 476 million tones (Figure 8).

With respect to DMO and policy planning of the coal marketing, the supply fulfilment of domestic coal demand in 2020 and 2030 will be evaluated. According to BPPT, the Indonesian coal demand is forecasted about 156 million tons in 2020 and 354 million tons in 2030. When the total coal demand is plotted in the supply curve developed based on coal production and operating cost forecasting (Figure 9), the following 


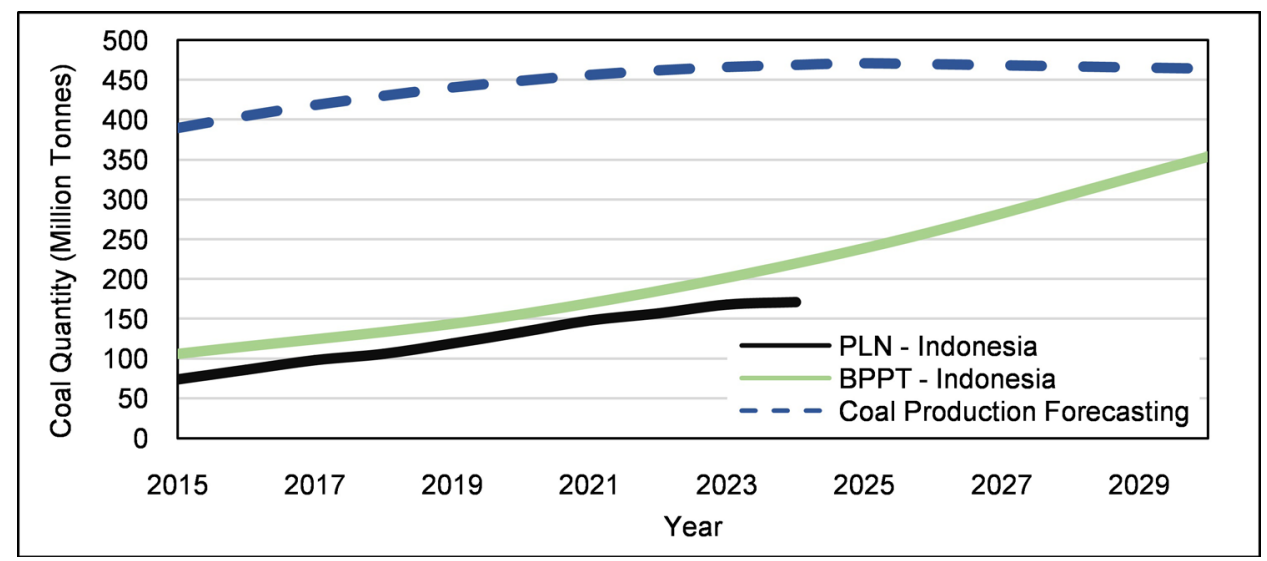

Figure 8. Forecasting of coal supply and demand in Indonesia.

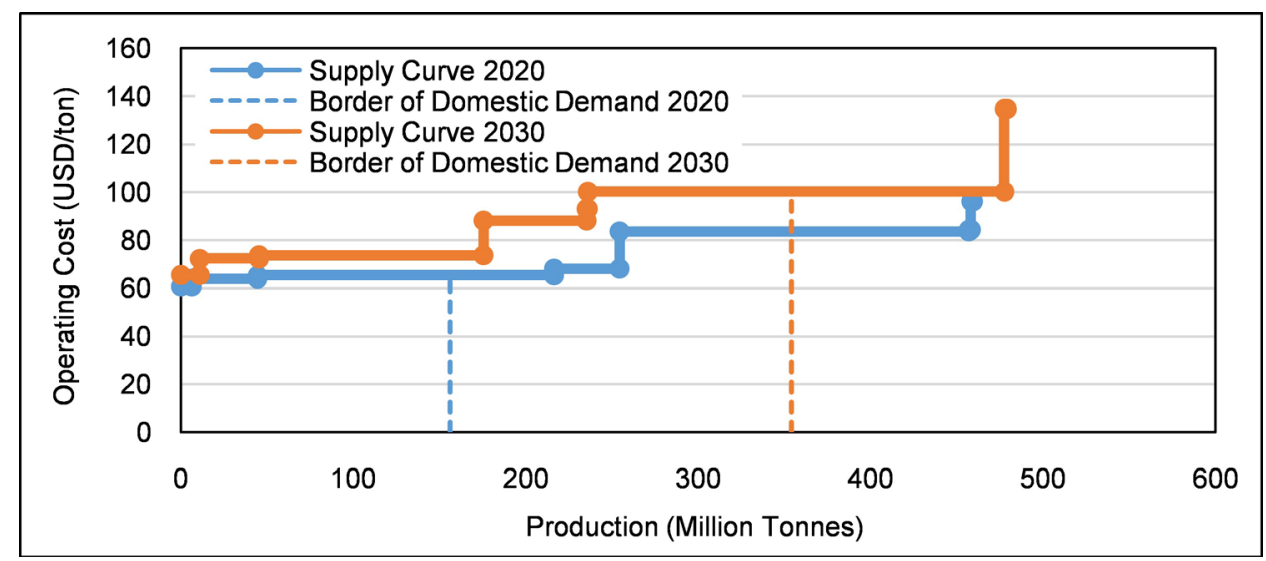

Figure 9. Indonesian coal supply curve based on the economic coal basin.

results are obtained:

- In 2020, coal for domestic demand is cheaper when is supplied by Central Sumatra, Tarakan, and Barito basins with an average supply cost of USD 64.8 per ton.

- In 2030, as the coal demand increases, all the economic coal basins except the Ombilin basin can be used to meet the domestic coal demand with an average supply cost of USD 84.6 per ton.

As the domestic coal demand is fulfilled by the aforementioned coal basins, there is significant impact on the coal supply cost in the export market. In 2020, the average supply cost of Indonesian coal in the export market is USD 78.0 per ton. Such cost is expected to increase to USD 100.6 per ton in 2030.

\section{Conclusion and Policy Implication}

Forecasting the coal production, operating cost as well as the reduction of coal reserves may be very beneficial in planning the national coal policies such as domestic coal marketing policy and the export market policy.

Indonesian coal production forecasting using Gompertz curve with the economic coal basin approach obtains the peak production of 485 million tonnes and peak year in 
2026. Kalimantan coal basins (Kutai, Barito, and Tarakan basins) play a greater role than Sumatra coal basins (Ombilin, Bengkulu, Central Sumatra and South Sumatra basins) in supporting the total national production. The decline in production of Kalimantan basins after year 2024 cannot be replaced by coal production from Sumatra basins.

The operating cost forecasting was carried out using trend analysis of historical data of the operating cost based on the cumulative availability curve whereby the operating cost/price will increase as the cumulative production increases. Logarithm trend was chosen assuming no significant changes in mining methods and equipment during the extraction period. Thus, future operating cost will merely depend on the quality of the coal produced in each basin. High CV coal production in Ombilin, Kutai, Bengkulu and South Sumatra basins will cost higher than the production of low CV coal in Barito, Tarakan and Central Sumatra basins. Production of high CV coal provides greater opportunities to the producer to increase the stripping ratio in order to obtain larger production than the production of low $\mathrm{CV}$ coal. As a result, the operating cost of high $\mathrm{CV}$ coal production is relatively higher than that of low CV coal.

Coal production and operating cost forecasting can be used as defining factors to establish better coal marketing policy. In 2020 the coal supply for domestic use will be cheaper if supplied from Central Sumatra, Tarakan, and Barito basins with an average supply cost of USD 64.8 per ton. With the increase of domestic coal demand in 2030, all the coal basins except Ombilin basin need to supply the domestic coal demand with an average supply cost of USD 84.6 per ton. In the export market supply, the minimum coal price from Indonesia is expected to increase from originally USD 78.0 per ton in 2020 to USD 100.6 per ton in 2030.

\section{References}

[1] Statistical Data of Energy Information Administration. http://www.eia.gov/beta/international/data/browser/

[2] Belanina, E. (2013) Multimodal Coal Transportation in Indonesia. Master's Thesis in Urban, Port, and Transport Economics, Erasmus University Rotterdam. https://thesis.eur.nl/pub/14848/MA-thesis-Belanina-FINAL-report-on-Indonesia.pdf

[3] Kamandanu, B., on Behalf of Indonesian Coal Mining Association (2011) Indonesian Coal Mining Outlook. International Energy Agency (IEA) Workshop on “Coal Market Outlook”, Beijing, 14 April 2011. https://www.iea.org/media/weowebsite/workshops/weocoal/05_02_KAMANDANU.pdf

[4] Patzek, T.W. and Croft, G.D. (2010) A Global Coal Production Forecast with Multi-Hubbert Cycle Analysis. Energy, 35, 3109-3122. https://doi.org/10.1016/j.energy.2010.02.009

[5] Hook, M., Zittel, W., Schindler, J. and Aleklett, K. (2010) Global Coal Production Outlooks Based on a Logistic Model. Fuel, 89, 3546-3558. https://doi.org/10.1016/j.fuel.2010.06.013

[6] Mohr, S.H. and Evans, G.M. (2009) Forecasting Coal Production until 2100. Fuel, 88, 20592067. https://doi.org/10.1016/j.fuel.2009.01.032

[7] Geological Agency of the Republic of Indonesia (2014) Executive Summary: Pemutakhiran Data dan Neraca Sumber Daya Energy Status 2014. Ministry of Energy and Mineral Resources, Republic of Indonesia. 
http://psdg.bgl.esdm.go.id/images/stories/neraca/neraca_2014/Executive\%20Summary\%20 Neraca\%20Energi\%202014\%20rev\%20pusdatin.pdf

[8] BP Statistical Review of World Energy 2014.

http://www.bp.com/en/global/corporate/energy-economics/statistical-review-of-world-ener gy.html

[9] Horkel, A. (1989) On the Plate-Tectonic Setting of the Coal Deposits of Indonesia and the Philippines. Mitteilungen der Oesterreichischen Geologischen Gesellschaft, 82, 119-133. http://www2.uibk.ac.at/downloads/oegg/Band_82_119_133.pdf

[10] Koesoemadinata, R.P. (2001) Outline of Tertiary Coal Basin of Indonesia. Berita Sedimentologi, 15, 1-27.

[11] Lucarelli, B. (2010) The History and Future of Indonesia's Coal Industry: Impact of Politics and Regulatory Framework on Industry Structure and Performance. Working Paper 93, Program on Energy and Sustainable Development, Stanford University, USA. https://pesd.fsi.stanford.edu/sites/default/files/WP_93_Lucarelli_revised_Oct_2010.pdf

[12] Hook, M. (2014) Depletion Rate Analysis of Field and Regions: A Methodological Foundation. Fuel, 121, 95-108. https://doi.org/10.1016/j.fuel.2013.12.024

[13] Hook, M., Li, J., Oba, N. and Snowden, S. (2011) Descriptive and Predictive Growth Curves in Energy System Analysis. Natural Resources Research, 20, 103-116.

link.springer.com/article/10.1007/s11053-011-9139-z https://doi.org/10.1007/s11053-011-9139-z

[14] Yu, S. and Wei, Y. (2012) Prediction of China's Coal Production-Environmental Pollution Based on a Hybrid Genetic Algorithm-System Dynamics Model. Energy Policy, 42, 521529. https://doi.org/10.1016/j.enpol.2011.12.018

[15] Ward, J. (2008) Peak Phosphorus: Quoted Reserves vs. Production History. Published by Energy Bulletin on 2008-08-26.

http://www.resilience.org/stories/2008-08-26/peak-phosphorus-quoted-reserves-vs-product ion-history

[16] Vikstrom, H., Davidsson, S. and Hook, M. (2013) Lithium Availability and the Future Production Outlooks. Journal of Applied Energy, 110, 252-266.

https://doi.org/10.1016/j.apenergy.2013.04.005

[17] Bardi, U. and Pagani, M. (2008) Peak Minerals. The Oil Drum: Europe. http://www.theoildrum.com/node/3086

[18] Hook, M. and Aleklett, K. (2010) Trends in U.S. Recoverable Coal Supply Estimates and Future Production Outlooks. Journal of Natural Resources Research-International Association for Mathematical Geology, 19, 189-208. http://link.springer.com/article/10.1007/s11053-010-9121-1

[19] Wallan, P., Davidsson, S., Johansson, S. and Hook, M. (2014) Phosphate Rock Production and Depletion: Regional Disaggregate Modelling and Global Implications. Journal of Resources, Conservation and Recycling, 93, 178-187. https://doi.org/10.1016/j.resconrec.2014.10.011

[20] Livernois, J.R. and Uhler, R.S. (1987) Extraction Cost and the Economics of Nonrenewable Resources. Journal of Political Economy, 95, 195-203. http://www.jstor.org/stable/1831306 https://doi.org/10.1086/261448

[21] Reynolds, D.B. (1999) The Mineral Economy: How Prices and Costs Can Falsely Signal Decreasing Scarcity. Ecological Economics, 31, 155-166. https://doi.org/10.1016/S0921-8009(99)00098-1

[22] Rosyid, F.A. and Adachi, T. (2015) Indonesian Coal Production Forecasting Method Using 
Logistic Curves: Evaluation Based on the Type of Coal Production License. Proceeding of the Mining and Materials Processing Institute of Japan Spring Meeting, Chiba, 27-29 March 2015. https://confit.atlas.jp/guide/event/mmij2015a/subject/3406/detail

[23] Petromindo.com in Cooperation with Indonesian Coal Mining Association (2014) Indonesian Coal Book 2014/2015.

[24] Pricewaterhouse Coopers (2007) Mine Indonesia 2007.

[25] PT. Adaro Energy, Tbk. 2008-2013. Annual Report.

[26] PT. Bumi Resources, Tbk. 2010-2013. Annual Report.

[27] PT. Baramulti Suksessarana, Tbk. 2012-2013. Annual Report.

[28] PT. Indika Energy, Tbk. 2009-2013. Annual Report.

[29] PT. Berau Coal Energy, Tbk. 2010-2013. Annual Report.

[30] PT. Bukit Asam, Tbk. 2006-2013. Annual Report.

[31] PT. Harum Energy, Tbk. 2010-2013. Annual Report.

[32] PT. Borneo Lumbung Energy \& Metal, Tbk. 2011-2013. Annual Report.

[33] PT. Bayan Resources, Tbk. 2010-2013. Annual Report.

[34] PT. Indo Tambangraya Megah, Tbk. 2007-2013. Annual Report.

[35] The Electricity State Company of Indonesia (2014) Rencana usaha penyediaan tenaga listrik 2015-2024.

http://www.djk.esdm.go.id/pdf/RUPTL/RUPTL\%20PLN\%202015-2024.pdf

[36] Center for Energy Resources Development Technology-Agency for Assessment and Aplication of Technology (2014) Indonesia Energy Outlook 2014: Energy Development in Supporting Fuel Substitution Program.

\section{Submit or recommend next manuscript to SCIRP and we will provide best service for you:}

Accepting pre-submission inquiries through Email, Facebook, LinkedIn, Twitter, etc.

A wide selection of journals (inclusive of 9 subjects, more than 200 journals)

Providing 24-hour high-quality service

User-friendly online submission system

Fair and swift peer-review system

Efficient typesetting and proofreading procedure

Display of the result of downloads and visits, as well as the number of cited articles

Maximum dissemination of your research work

Submit your manuscript at: http://papersubmission.scirp.org/

Or contact nr@scirp.org 